\title{
Erratum to: Total Trihalomethanes in Public Drinking Water Supply and Birth Outcomes: A Cross-Sectional Study
}

\author{
Sanjaya Kumar · Steve Forand · Gwen Babcock • \\ Wayne Richter · Thomas Hart · Syni-An Hwang
}

Published online: 17 May 2014

(C) Springer Science+Business Media New York 2014

Erratum to: Matern Child Health J (2014) 18:996-1006

DOI 10.1007/s10995-013-1328-4

The original publication of this article was submitted and published without the names of two co-authors, Wayne Richter and Thomas Hart in the author group, which has been corrected with this erratum.

The online version of the original article can be found under doi:10.1007/s10995-013-1328-4.

S. Kumar $(\bowtie) \cdot$ S. Forand · G. Babcock · W. Richter .

T. Hart - S.-A. Hwang

Center for Environmental Health, New York State Department

of Health, Albany, NY, USA

e-mail: sxk10@health.state.ny.us

S. Forand

e-mail: spf02@health.state.ny.us

G. Babcock

e-mail: gdb02@health.state.ny.us

W. Richter

e-mail:wxrichte@gw.dec.state.ny.us

T. Hart

e-mail: thomashart109@gmail.com

S.-A. Hwang

e-mail: Sah02@health.state.ny.us

W. Richter

New York State Department of Environmental Conservation,

Albany, NY, USA 